Egyptian Journal of Rabbit Science, 26(1): 57- 87(2016)

\title{
COMPARATIVE STUDIES ON REPRODUCTIVE MALE RABBITS AS AFFECTED BY THERAPEUTIC OF IVERMECTIN OR BOTH OF GARLIC AND CINNAMON OILS TREATMENTS. b. BIOCHEMICAL BLOOD, HORMONES AND SEMEN CHARACTERISTICS IN MALE RABBIT
}

\author{
El-Sawy ${ }^{1}$, M.A.; M.E. El-Speiy ${ }^{1}$; M.A. Tony ${ }^{2}$ and T.A. Sadaka \\ ${ }^{1}$ Anim. Prod. Res. Inst., Agric. Res. Center, Ministry of Agric., Egypt. \\ ${ }^{2}$ Fac.Vet. Med. Cairo Univ. Giza Egypt._E-mail: Elsawy1966@Gmail.com
}

Thirty-six V-line male rabbits ten months age, average weight 3.5 $\mathrm{kg}$ were used. They were allocated randomly into six equal groups. First and second were served as a negative (NC) and positive (PC) control. Third group was injected by double dose (1 $\mathrm{mg} / \mathrm{kg}$ body weight) of ivermectin (IV) via subcutaneous injection, fourth, fifth and sixth groups were treated with 5\% garlic oil $(G O)$, 5\% cinnamon oil (CO) and 5\% garlic oil $+5 \%$ cinnamon oil mixture $(\mathrm{MO})$, respectively. Rabbits were treated $G O, C O$ and $M O$ received daily topically treatment for 7 successive days. Groups $P C$ and $I V$ were treated with paraffin oil and ivermectin. Blood samples were collected at 1, 7 and 14 days of treatment to biochemical analysis. Semen characteristics and reaction time (libido) were recorded.

Results showed that there were a significant $(P \leq 0.05)$ decreased in total protein, albumin, globulin, testosterone, semen characteristics, TAC in rabbits infested groups compared with NC group. But there were a significant $(P \leq 0.05)$ increase in ALT, AST, creatinine, urea and uric acid, cortisol, $T_{3}$ and $T_{4}, M A D$ in the rabbits infested groups compared with NC group. Rabbits treated with ivermectin recorded a significant $(P \leq 0.05)$ decrease at 1 and 7 days in serum total protein, albumin compared with other groups, while, globulin decreased gradually from day 1, 7 and 14 comparable with other groups. Serum total protein, albumin, ALT, AST, creatinine, urea and uric acid were increased toward to NC group at $7^{\text {th }}$ and $14^{\text {th }}$ days of therapeutic.

Garlic and cinnamon oils caused a decrease in ALT, AST, creatinine, urea and uric acid with time compared with $P C$ and $I V$ groups. While, injected ivermectin for infested rabbits led to significant $(P \leq 0.05)$ increase in cortisol, $T_{3}$ and $T_{4}$ hormones at $1^{\text {th }}, 7^{\text {th }}$ and $14^{\text {th }}$ 
days. Likewise, testosterone significant $(P \leq 0.05)$ increased at $7^{\text {th }}$ and $14^{\text {th }}$ day's similarity therapeutic by oil treated groups. Also, they recorded a significant $(P \leq 0.05)$ decreasing at 14 days in $M A D$ and significant $(P \leq 0.05)$ increasing in TAC compared with other groups. Semen volume, sperm concentration, advanced motility and live sperm\% were significantly decreased $(P \leq 0.05)$ of infested rabbits compared with NC group, while abnormal sperm\% increased. In the same context, the semen characteristics were significant increased in all therapeutic groups at $7^{\text {th }}$ and $14^{\text {th }}$ toward the NC group.

Conclusively, five percent of garlic or cinnamon oil is so effective in treating rabbits injured by Sarcoptec scabei compared to ivermectin with no side effects on liver and kidney functions or semen characteristics.

Key words: Sarcoptec Scabei, Ivermectin, Cinnamomum zeylanicum, Allium sativum oils, Hematology Biochemistry, Antioxidant enzymes, hormones, semen quality.

Sarcoptes scabiei is a burrowing mite that inhabits the epidermis of the skin causing sarcoptic mange in mammals and it's a highly contagious parasite (Walton and Currie, 2007). Sarcoptes scabiei is an important rabbit ectoparasite because of the possibility of zoonotic infection and considerable losses in weight, productivity, wool, and fiber quality (Harrenstien et al., 1995). In such conditions, animals affected with Sarcoptes scabiei may affected by other health problems such as dermatitis, pyoderma, sometimes eczema and urticarial. Several constraints such as resistance of Sarcoptes scabiei to synthetic medicaments due to the repeated use of the same mode of action drugs in infected animals. Side effects of medicaments, the long residual properties of most of the synthetic drugs available in the use justify the cause to find alternative approaches to control Sarcoptes scabiei mite (Khan et al., 2012). Mahmoud et al., (2014) mentioned that the severely infested rabbits exhibited significantly reduced total white blood cell, lymphocyte, and eosinophil counts. Animals are infested with skin infection mange cussed disturbed the oxidant/antioxidant balance by mites and some oxidative substances would be constantly generated in animals (Singh et al., 2012). In addition, the immune status of the animal, the nutritional status and oxidative stress may play very important roles in the pathogenesis of this 
disease (Singh et al., 2011). When these substances generated overloaded the antioxidant defense, the free radicals could interact with endogenous macromolecules, alter the cellular functions, and induce some serious adverse effects on the skin, including edema, erythema, wrinkling, inflammation and autoimmune reaction (Muthukumaran et al., 2008).

The levels of malonyldialdehyde (MAD) in the infested rabbits were markedly increased, and this was associated with the deterioration of cells, the development of skin lesions and the clinical manifestation of mange (Kanbur et al., 2008). Sarasa et al. (2011) reported that the sarcoptic mange was associated with reduced size-corrected testes mass in Iberian ibex which supports the hypothesis that parasitism is a determining factor in gonad in plasticity in male mammals.

Therefore, the present study was designed to investigate the role of ivermectin, garlic and cinnamon oils against Sarcoptic scabiei and their effects on hematology, biochemistry, antioxidant enzymes, hormones and semen quality.

\section{MATERIALS AND METHODS}

\section{Experimental animals:}

Thirty-six V-line male rabbits ten months age weighting about $3.5 \mathrm{~kg}$ were used for the present study. They were housed in clean, separate and wire-floored metal cages and maintained under standard laboratory conditions. The ambient temperature was $25 \pm 2{ }^{\circ} \mathrm{C}$ with $55-64 \%$ relative humidity and a $16 \mathrm{~h}$ light and $8 \mathrm{~h}$ dark. They were allowed to a standard pellet diet $(17 \%$ crude protein, $2.56 \%$ crude fat and $2500 \mathrm{Kcal} / \mathrm{kg}$-ration digested energy and $12.5 \%$ crude fiber). Food and water were available ad libitum. Rabbits were kept under the same environmental conditions during the experimental period (30 days).

Experimental design: Rabbits were allocated into six equal groups each contain 6 males as follow:

Group 1: It was served as a negative control (non-infested and non-treated) (NC).

Group 2: It was served as positive control (infested and non-treated) (PC)

Group3: Infested rabbits were served as therapeutic group and treated with ivermectin injection by double therapeutic dose $1 \mathrm{mg} \mathrm{kg}^{-1}$ of ivermectin via subcutaneous injection (IV) (Atakisi et al., 2009). 
Group 4: Infested rabbits were served as therapeutic group and treated with $5 \%$ garlic oil (Allium sativum) in paraffin oil (GO).

Group 5: Infested rabbits were served as therapeutic group and treated with $5 \%$ cinnamon oil (Cinnamomum zeylanicum) in paraffin oil (CO).

Group 6: Infested rabbits were served as therapeutic group and treated with mix of garlic and cinnamon oils, (5\% garlic oil + cinnamon oil 5\%) in paraffin oil (MO).

Groups treated with GO, $\mathrm{CO}$ and $\mathrm{MO}$ received daily topically treatment embrocating by $2.5 \mathrm{ml}$ of therapeutic oil for 7 successive days. PC and IV groups were treated locally with paraffin oil and double therapeutic dose ivermectin by injection $1 \mathrm{mg} \mathrm{kg}^{-1}$ of ivermectin, respectively.

Treatments on the infested areas in limbs and pinna of rabbits were done after cleaning with worm water and remove of scabs according to Fichi et al., (2007a). Rabbits in all groups were followed up by skin scaping and examination under stereomicroscope till complete recovery.

\section{Essential oils:}

The essential oils used in this study were provided by the medicinal and aromatic plants division belonging to Research Institute, Agricultural Research Center in Egypt. The chemical analysis of essential oils was done with a GC - ULTRA gas chromatograph according to Adams (2007).

\section{Biochemical Analysis:}

All blood samples of $3 \mathrm{~mL}$ were collected from the ear vein at times immediately before injection of ivermectin as control and on 1, 7 and 14 days after treatment. Blood samples were centrifuged at 3000 r.p.m. for $20 \mathrm{~min}$ to separate a clear serum. Collected serum samples were subjected to biochemical analysis of urea and creatinine (Henry, 1974), alanine aminotransferase (ALT), aspartate aminotransferase (AST) activities (Reitman and Frankel, 1957), total protein (Sonnenwirth and Jarett, 1980), creatinine (Henry, 1974), albumin (Doumas, 1971), globulin was calculated, malonyaldehyde (MAD) and total antioxidant capacity (TAC) (Ippoushi et al., 2005). All biochemical parameters were analyzed by commercially available kit methods. GNW-Model: SM721Spectrophotometers, Absorbance Microplate Reader and other laboratory equipment aids were used for biochemical analysis. Moreover, each parameter was done according to the instructions of its kit.

Serum testosterone concentration was determined using RIA method according to Wilke and Utley (1987). Triiodothyronine $\left(\mathrm{T}_{3}\right)$, thyroxin $\left(\mathrm{T}_{4}\right)$ 
and cortisol hormones determination were done according to Abdel-Fattah et al., (2011) using radioimmunoassay (RIA) technique.

\section{Semen Quality:}

Advanced sperm motility from at least three fields was examined at 37 ${ }^{\circ} \mathrm{C}$ under a phase microscope at $40 \times$ and assessed from 0 to $100 \%$. A weak eosin solution was used at a rate of 1:99 before counting the cells, for evaluation of sperm concentration $\left(\times 10^{6} / \mathrm{ml}\right)$ as to Smith and Mayer (1955) by the hemocytometer slide. The percentage of live spermatozoa was determined by using stains that penetrate cells with damaged membranes. The total number of motile sperm was calculated by multiplying percentage of motile sperm by total sperm outputs. (Correa and Zavos, 1996).

\section{Reaction time (libido):}

A matured cyclic doe (teaser) was introduced to the buck every 2 weeks interval to monitor their sex drive. In this study, reaction time was considered as an indication of libido. The time in seconds it took for the rabbit bucks to sniff, groom and mount the female was recorded with a stop watch, and libido scored using the scoring pattern of 1-5 (no libido - high libido) as described by (Chibundu, 2005).

\section{Statistical analysis:}

All data were subjected to analysis of variance according to the statistical analysis system (SAS, 2002). The differences among groups means were tested by using Duncan's multiple rang test (Duncan, 1955).

\section{RESULTS AND DISCUSSION}

\section{Chemical composition of the essential oils:}

Gas chromatography analysis of garlic and cinnamon oils is cited by ElSpeiy et al., (2016a).

\section{Biochemical serum blood analysis:}

Concerning biochemical serum blood analysis at 14 day's post treatment, Figure (1) showed a significant $(\mathrm{P} \leq 0.05)$ decreased in blood serum total protein, albumin and globulin in $\mathrm{PC}$ compared with $\mathrm{NC}$ group. While, treated rabbits with ivermectin recorded a significant $(\mathrm{P} \leq 0.05)$ decrease (at day 1and 7 ) in serum total protein and albumin when compared with other groups. 

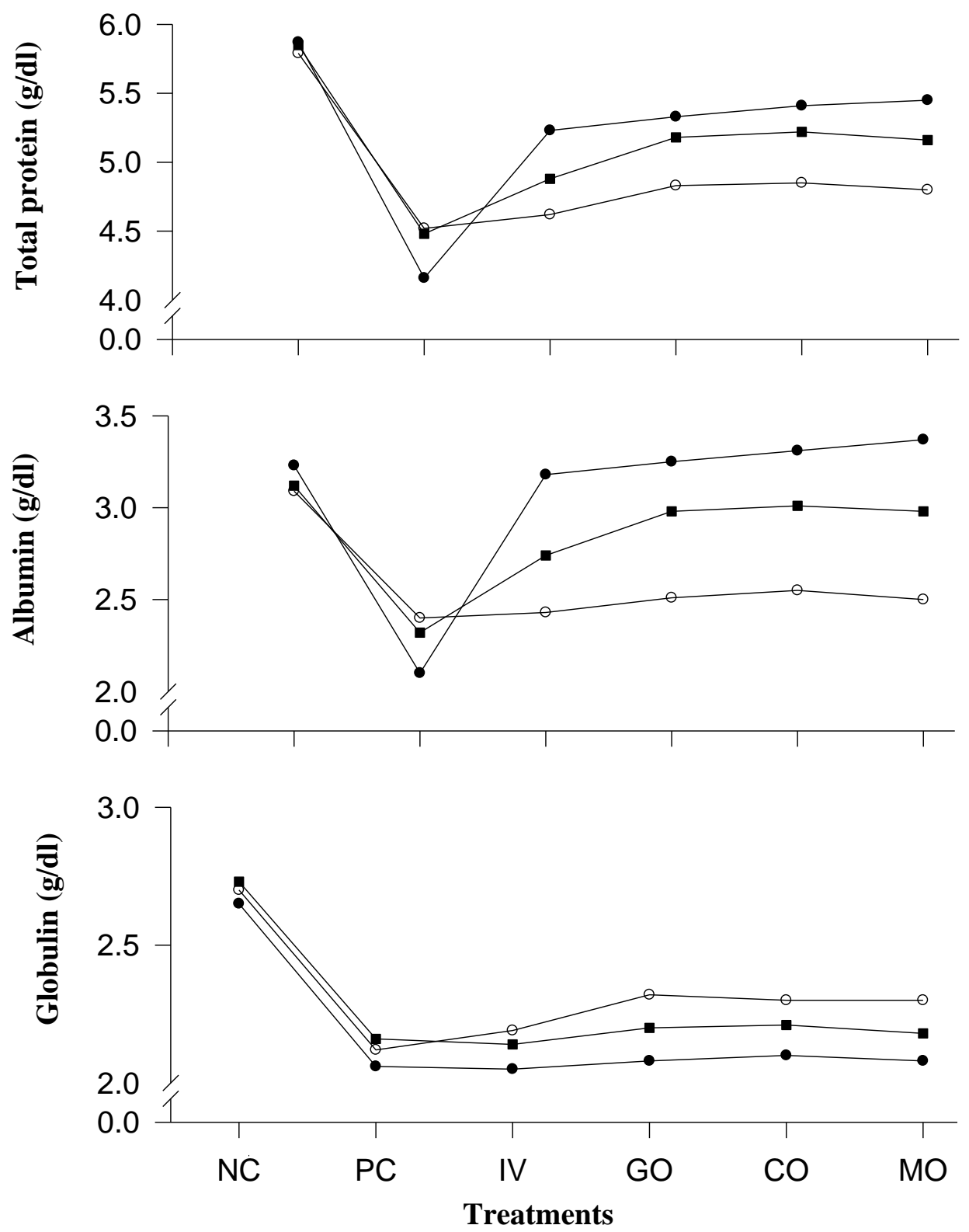

Day $1 \multimap$ Day $7 \multimap$ Day $14 \multimap$

Figure 1: Effect of ivermectin, garlic and cinnamon oils on total protein, albumin and globulin levels of male rabbits. 
Serum globulin decreased gradually from day 1, 7 and 14 comparable with other groups. However, serum total protein and albumin increased toward values of $\mathrm{NC}$ group at $7^{\text {th }}$ and $14^{\text {th }}$ days of treatment. But globulin was significantly $(\mathrm{P} \leq 0.05)$ decreased in its level compared with NC group.

There are many factors which can affect the level of albumin circulating in the blood. Chronic liver disease causes decrease in the amount of albumin produced, and consequently, the level of albumin in the blood is reduced. Albumin is also part of most automated chemistry screening panels (Canadian liver foundation, 2015). Albumin is a major protein which is formed by the liver (Gines and Arroyo, 2000). Albumin is the major extracellular source of thiols. Albumin can also limit the production of reactive oxidative species by binding free copper, an ion known to be particularly important in accelerating the production of free radicals (Quinlan et al., 1998). This study revealed that oils treated groups showed significant difference $(\mathrm{P} \leq 0.05)$ in serum total protein, albumin and globulin when compared with NC group. These results were in agreement with those obtained for rabbits (Seddiek et al., 2013). On the other hand, rabbits in PC group showed a significant decreased in serum total protein, albumin, and globulin when compared with the corresponding values of other groups. Atakisi et al., (2009) suggested that ivermectin did not alter protein and albumin parameters during therapeutic course. Emtenan et al., (2010) mentioned that rabbits treated with cinnamon oil and infested with sarcoptes showed elevation of protein, albumin and globulin when compared with positive control group. Tollba and Hassan (2003) stated that garlic treatment led to an increase in the gamma globulin production from plasma cells. Mohamed et al., (2016) mentioned that garlic extract supplementation increased blood serum total protein and globulin on growing lambs. Jenkins (2000) and Meredith and Rayment (2000) stated that liver inflammation and necrosis (such as that caused by parasites) is responsible for making albumins; therefore, decreases in serum albumin levels (Figure 1).

Regarding biochemical analysis 14 day's post treatment, results showed a significant $(\mathrm{P} \leq 0.05)$ increase in serum blood ALT, AST, creatinine, urea and uric acid in the PC group compared with NC group. Treated rabbits with ivermectin recorded a significant $(\mathrm{P} \leq 0.05)$ increased at 1,7 and 14 days in ALT, AST enzymes, creatinine, urea and uric acid compared with other groups (Figures 2 and 3). On the other hand, treated rabbits with oils showed significant $(\mathrm{P} \leq 0.05)$ decrease in ALT, AST, creatinine, urea and uric acid 

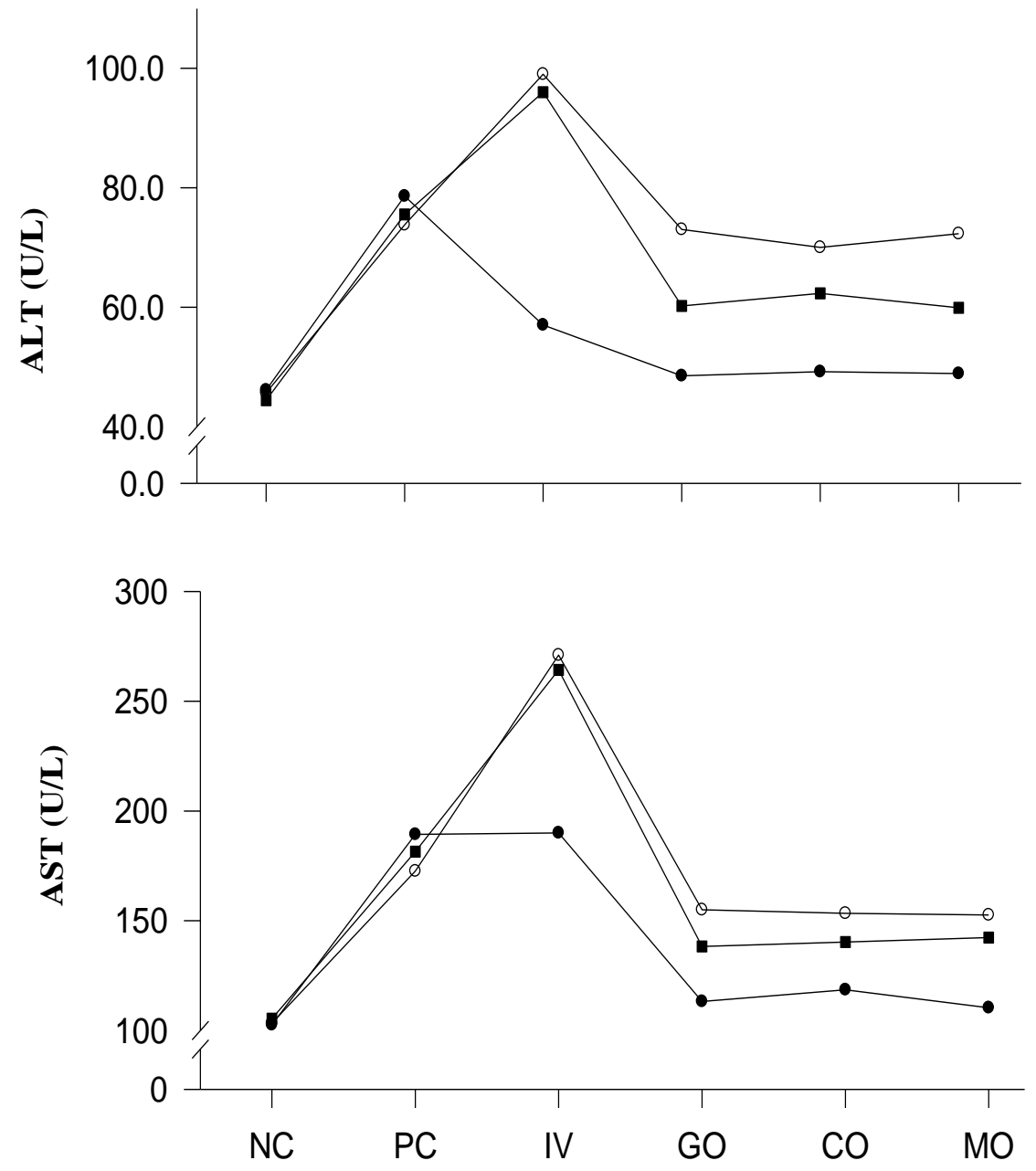

Treatments

\begin{tabular}{|c|c|}
\hline Day $1-0$ & Day $7 \longrightarrow$ Day 14 \\
\hline
\end{tabular}

Figure2: Effect of ivermectin, garlic and cinnamon oils on serum ALT and AST levels of male rabbits. 

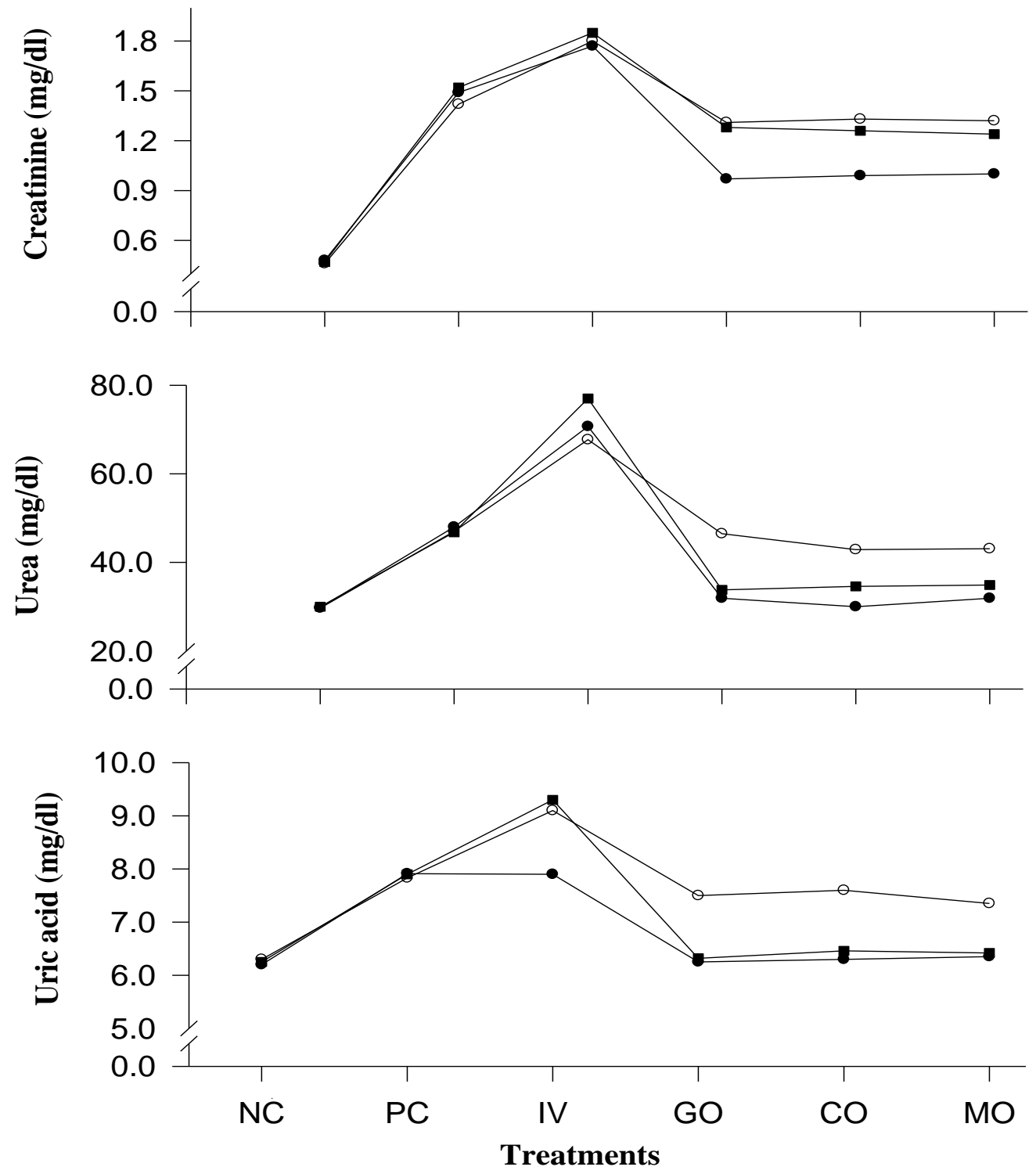

Day $1 \longrightarrow$ Day $7 \longrightarrow$ Day $14 \longrightarrow$

Figure 3: Effect of ivermectin, garlic and cinnamon oils on serum creatinine, urea and uric acid levels of male rabbits. 
compared with PC group and IV group. In the same context data illustrated that treatment with oils decreased ALT, AST, creatinine, urea and uric acid with time compared with PC and IV groups during the experiment (Figure 2).

Liver enzymes (ALT and AST) are commonly measured clinically as a part of a diagnostic evaluation of hepatocellular injury to determine liver health (Wang et al., 2012). Alanine aminotransferase this enzyme is of limited use for rabbit liver disease, if ALT is significantly elevated, it may indicate liver inflammation and necrosis (such as that caused by parasites, and or hepatic lipidosis) (Jenkins, 2000).

The positive control rabbits showed a significant increase in serum ALT and AST levels. This may be attributed to the ear tissues damage induced by mite's infestation and its toxic excretory products. Such results were in agreement with those mentioned for rabbits (Seddiek et al., 2013 and Mahmoud et al., 2014). Biochemical analysis indicated that the levels of ALT and AST in rabbits significantly $(\mathrm{P} \leq 0.05)$ increased in rabbits in $\mathrm{PC}$ and IV. Such results indicated an adverse effect of ivermectin on the liver and results were in agreement with those mentioned for macrocyclic lactones for the treatment of rabbits (Eman and Abdella, 2000). Liver function was negatively affected, which was monitored by increasing ALT and AST after ivermectin injection in rabbits (Eman and Abdella, 2000). Serum ALT, AST, urea, and creatinine levels were significantly $(\mathrm{P} \leq 0.05)$ increased after 28 days of treatment with ivermectin in swine and cattle (Slantna et al., 1989). The toxic effects of ivermectin on liver and kidney functions were transient, and the treated rabbits required not less than 3 months after injection of ivermectin to regain their normality (Eman and Abdella, 2000), in same context Arise and Malomo (2009) confirmed a significant increase in both enzyme activities for IV group with highest increments indicating the incidence of hepatic injuries due to ivermectin medication. Also, Ashang (2009) showed the effects on some liver function enzymes such as ALT and AST in ivermectin treated in Wistar Albino rats. The findings of raised enzymes following ivermectin administration, suggest that, in liver disease, the use of ivermectin must be done with caution (Hutchinson et al., 2009). Transient non-significant renal disturbances were observed which suggested that ivermectin seem to cause minor damage to the glomeruli (Arise and Malomo, 2009). Reduced renal blood flow associated with high serum urea concentration may impair the secretory function of the kidney. Malfunction in the glomerular filtration results in retention of substances including urea, 
uric acid and creatinine and this might be responsible for their high serum levels in the treated groups (Selvakumar et al., 2013).

Treatment with garlic oil reduced serum ALT and AST enzymes, creatinine, urea and uric acid towards the normal levels on the day 14 post treatment (Figures 2 and 3). This is may be due to the acaricidal effect of garlic oil. On the other hand, the obtained results disagreed with the findings of Ibrahim et al., (2000) on rabbits. The harmony in our results showed nonsignificant changes of creatinine in all treated rabbits except that treated with ivermectin which showed a significant $(\mathrm{P} \leq 0.05)$ increase (Figure 3$)$. These results indicated that the garlic extract has no harmful effect on kidney functions. The obtained results endorsed the results of El-Shater et al., (1998) on rats. Emtenan et al., (2010) mentioned that therapeutic infested rabbits with cinnamon oil (1.25\%) showed normal liver and kidney functions. Saber et al., (2014) indicated that treating animals with cinnamon led to improvement in the histological structure of the kidney and ameliorative effect against damage.

Concerning biochemical serum blood analysis during treatment, showed the regulates significant $(\mathrm{P} \leq 0.05)$ decrease in serum testosterone, but increase in cortisol, $\mathrm{T}_{3}$ and $\mathrm{T}_{4}$ hormones in the $\mathrm{PC}$ compared with $\mathrm{NC}$ group, respectively (Figures 4 and 5). While, injected ivermectin for infested rabbits led to significant $(\mathrm{P} \leq 0.05)$ increase in cortisol, $\mathrm{T}_{3}$ and $\mathrm{T}_{4}$ hormones at $1^{\text {th }}, 7^{\text {th }}$ and $14^{\text {th }}$ days. Likewise, testosterone was significantly $(\mathrm{P} \leq 0.05)$ increased at $7^{\text {th }}$ and $14^{\text {th }}$ day's similar to treatment by oil. Clearly, at day $14^{\text {th }}$ the concentrations of testosterone, cortisol and $\mathrm{T}_{4}$ hormones comparable between $\mathrm{NC}$ and all oil groups (Figures 4 and 5).

Testosterone is a steroid hormone from the androgen group in mammals, reptiles, birds and other vertebrates. In mammals; testosterone is primarily secreted in the testicles of males and the ovaries of females, although small amounts are also secreted by the adrenal glands (Vodo et al., 2013).

Parasitism by (Sarcoptes scabiei) is known to affect the social behavior of hosts in host-pathogen systems (Hughes et al., 2004). Testis size is intimately associated with testosterone dynamics (Toledano-Díaz et al., 2007), and testosterone is predictive of a male's rank trajectory (Beehner et al., 2006), of likeliness to initiate aggressions (Virgin and Sapolsky, 1997) and of outcome of male-male interactions (Bergman et al., 2006). Thus, through testosterone, a relationship between testes size and behavior is highly plausible. Free testosterone is the serum testosterone that is not bound to sex hormone 

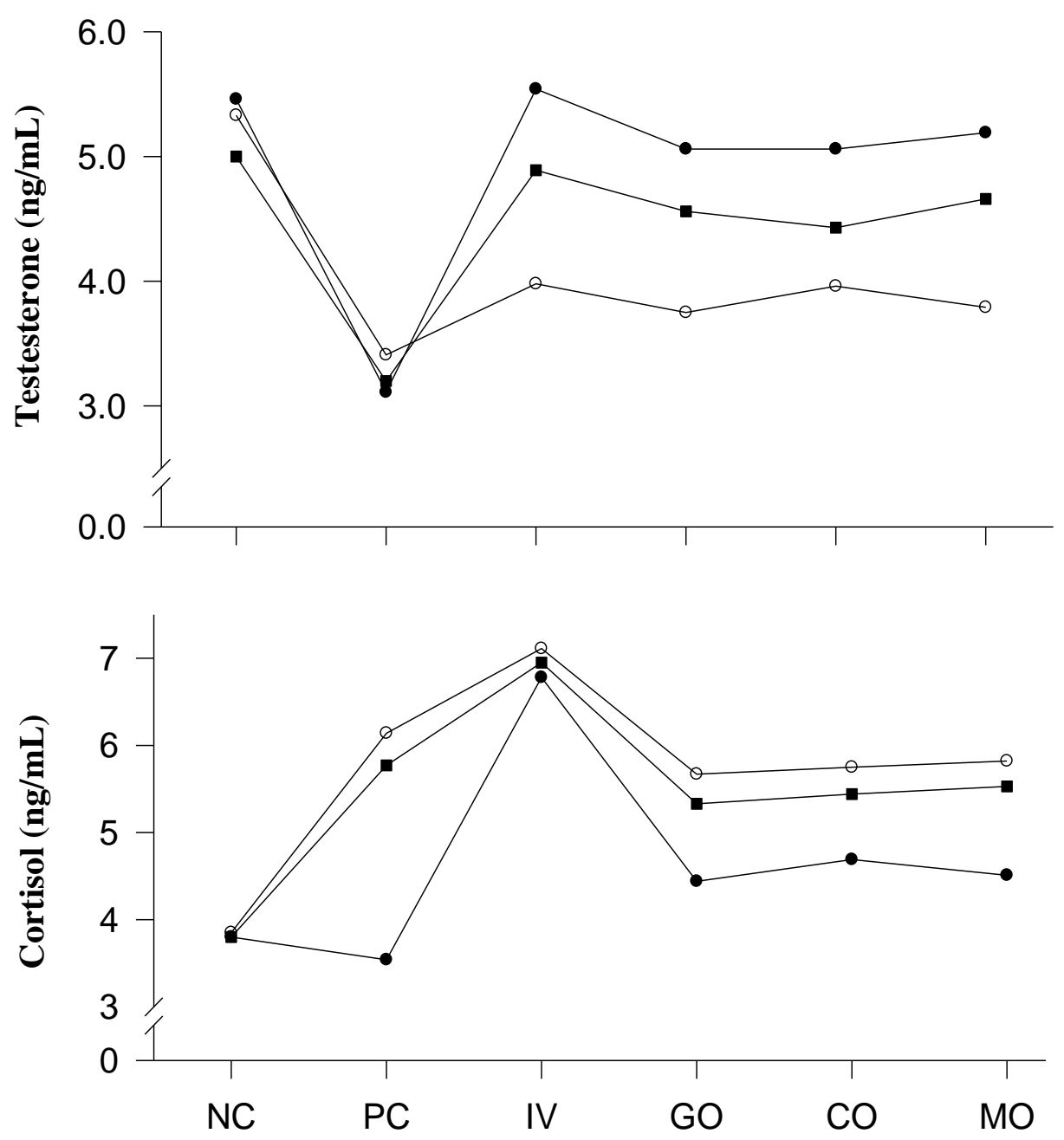

Treatments

Day $1 \multimap 0 \quad$ Day $7 \longrightarrow$ Day $14 \quad \longrightarrow$

Figure 4: Effect of ivermectin, garlic and cinnamon oils on serum testesterone and cortisol levels of male rabbits. 

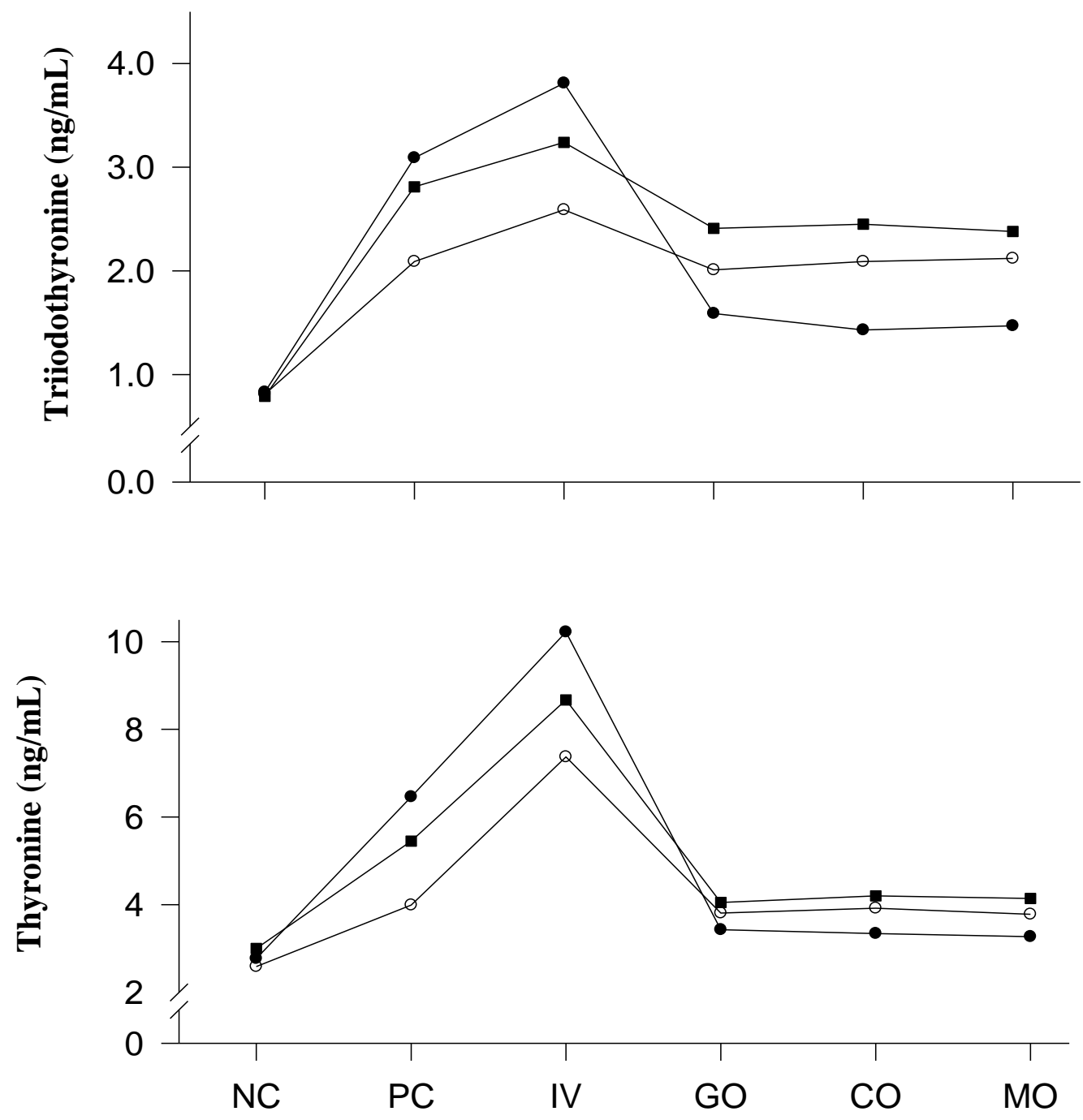

Treatments

Day $1 \longrightarrow$ Day $7 \longrightarrow$ Day $14 \quad \longrightarrow$

Figure 5: Effect of ivermectin, garlic and cinnamon oils on serum triiodothyronine $(\mathrm{ng} / \mathrm{mL})$ and thyronine $(\mathrm{ng} / \mathrm{mL})$ levels of male rabbits. 
binding globulin (SHBG) or albumin. It is free testosterone that is biologically active able to exert its effect by permeating a cell and activating its receptor (Kevin et al., 2012). The obtained data in Figure 3 revealed a significant increase in testosterone and free testosterone in IV and oils treated groups with a high increase in IV group that improve the male reproduction. Kadry et al., (2015) showed that ivermectin caused unobservable changes in serum testosterone and sex hormones binding globulin. Yuriko et al., (2001) suggested that dietary supplementation with garlic altered hormones associated with protein anabolism by increasing testicular testosterone in rats.

Cortisol is a steroid hormone produced by the zona fasciculata of the adrenal cortex and it is released in response to stress although it acts to restore homeostasis, prolonged secretion of cortisol, which may be due to excessive secretion or chronic stress, leads to major physiological changes, suppressing immune and reproductive functions (Muehlenbein and Watts, 2010). It is observed a trend towards an increase in serum cortisol levels in chronically infested animals. Serum cortisol is often used in stress and welfare assessments (Orihuela et al., 2009). However, it is important to consider that the nature of the aversive stimulus leads to major physiological changes. With respect to external parasites, serum cortisol levels have been related to tick deleterious in cattle. Tick deleterious also affected various characteristics of growth and metabolism in growing cattle (Garris et al.,1991), and serum cortisol levels also have been directly associated with intestinal parasite abundance in helminthic infestations (Kyriazakis and Day., 1998). Increasing level of cortisol in ivermectin treated rabbits is a clear indication of the stress condition of those animals (Marieb and Hoehn, 2010).

Physiological activities of free thyroid hormones depend on thyroxinebinding globulin (TBG), thyroxine-binding pre-albumin (TBPA) and albumin plasma concentrations. In acute Protein Energy Malnutrition (infestation status), free $\mathrm{T}_{4}$ levels may be either normal or high. After acute decreasing in thyroid hormone binding proteins, free $\mathrm{T}_{4}$ levels increased but when malnutrition prolonged free $\mathrm{T}_{4}$ levels decreased. For this reason it was reported that free $\mathrm{T}_{4}$ levels were important in explaining thyroid functions in children with PEM (Tibaldi and Surks, 1985).

Furthermore, the circulatory levels of $\mathrm{T}_{3}$ and $\mathrm{T}_{4}$ hormones have been found to play an important role in correlating the persistent infection as well as subclinical condition of infection (David et al., 1998). Similarly, in stressful animals, an increase in plasma cortisol concentration causes an 
alteration of neutrophil function and an increase in susceptibility to infection (Roth and Kaeberle, 1982).

The treatment with garlic extract has been shown to stimulate the release of cytokines such as IL-2, IFN- $\alpha$, IFN- $\gamma$ an increase in the natural killer activity and enhance phagocytic activity of peritoneal macrophages (Kyo et al., 1998). The therapeutic efficacy of garlic for its cytotoxic, antitumor, antifungal, antibacterial, antiviral and antiprotozoal properties showed that it was used traditionally since long time is thought to be caused by an organic sulphur compound 'Ajoene' (4,5,9 -trithiadodeca 1,6, 11triene-9-oxide) (Ledezma and Apitz, 1998). Further, garlic is also reported to contain selenium, vitamins A, B, C and E (Williamson, 2002).

\section{Oxidant serum blood analyses:}

Concerning biochemical analysis 14 day's post treatment, it was seen significant $(\mathrm{P} \leq 0.05)$ increase in MAD and significant decrease in TAC in PC and IV groups compared with NC group (Figure 6). On the contrary, treated rabbit with oils recorded significant $(\mathrm{P} \leq 0.05)$ decrease in MAD at 14 days and significant $(\mathrm{P} \leq 0.05)$ increase in TAC compared with other groups (Figure 6).

Regarding to oxidative stress induced by ivermectin injection a significant decrease in serum TAC levels were recorded in a positive relationship to the periods of experimental in IV group. On the contrary, the levels of MAD were significantly $(\mathrm{P} \leq 0.05)$ increased in treated group. In regard to oxidative stress, there was a significant increase in MAD and significant decrease in glutathione, glutathione peroxidase, glutathioneStransferase, superoxide dismutase, catalase and serum ascorbate in infested groups (Mahmoud et al., 2014). In agreement with our result, significant decrease in TAC of V-line rabbits injected by ivermectin was observed by (Atakisi et al., 2009). Ivermectin may produce free radicals and thus results in cytotoxic effect on the parasite. Ivermectin was reported to counteract against scabies agents by inducing free radicals associated damage and by decreasing antioxidant enzyme activity (Behera et al., 2011). These findings may suggest that ivermectin is a safe anti-parasitic drug for mammals but to less extent; it may have an effect on the balance between oxidants and antioxidants (El-Shenawy, 2010)

Carmia Borek, (2001) mentioned that the garlic extracts treated animals showed significantly decrease $(\mathrm{P} \leq 0.05)$ MAD as compared with $\mathrm{PC}$ and IV groups because the garlic extracts elicit antioxidant action by scavenging reactive oxygen species, enhancing the cellular antioxidant enzyme (e.g. 

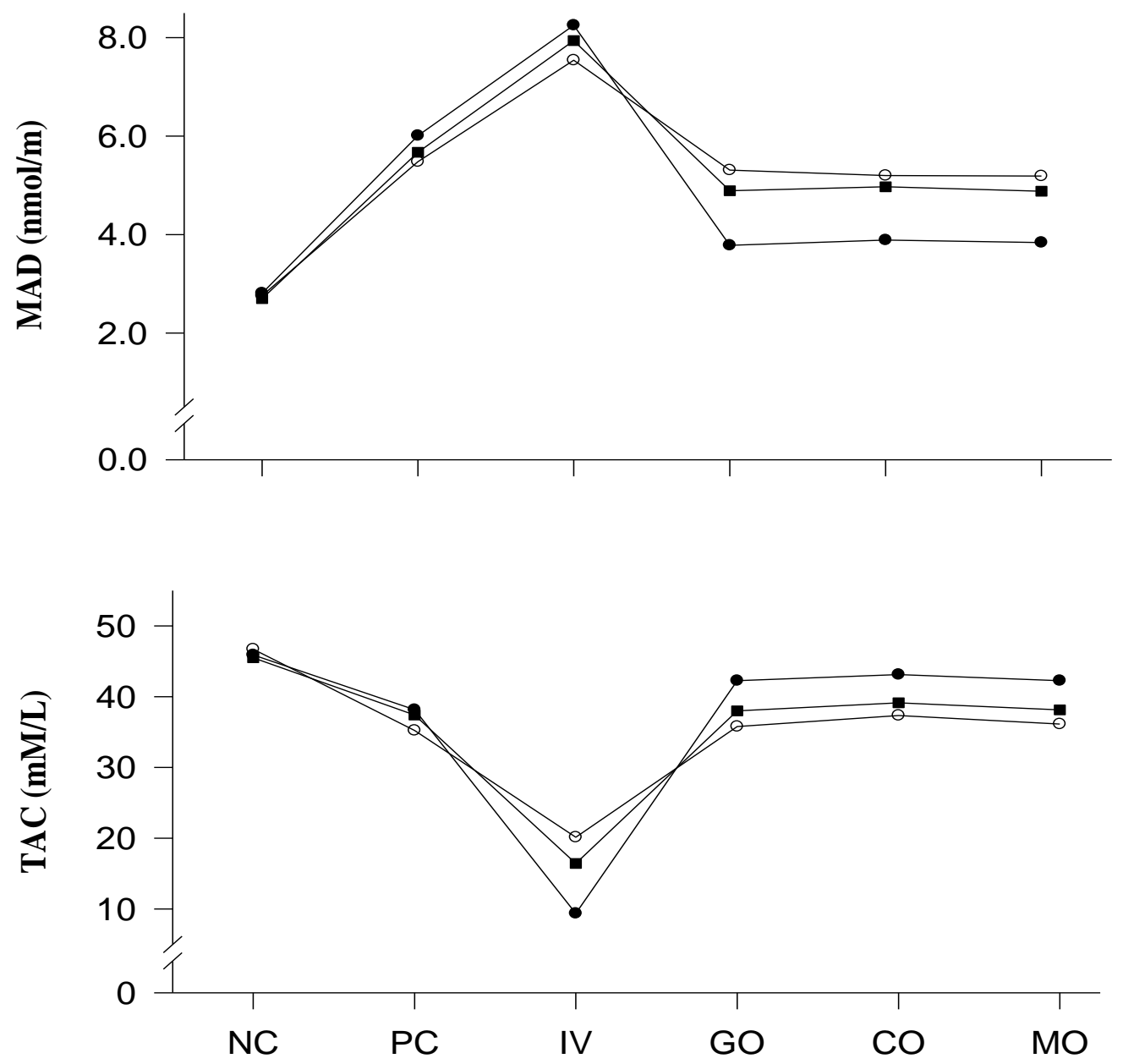

Treatments

Day $1 \multimap$ Day $7 \multimap$ Day $14 \quad \longrightarrow$

Figure 6: Effect of ivermectin, garlic and cinnamon oils on serum MAD and TAC levels of male rabbits. 
superoxide dismutase, catalase and glutathione peroxidase) and increasing glutathione in the cells. Ide et al., (1996) reported that garlic and its major organo sulfur constituents had a scavenging effect on hydrogen peroxide, and inhibited the chain of oxidation induced by a hydrophilic radical initiation.

Moreover, the essential cinnamon oil mechanism depended on constituents approximately 20-26 compounds to effect on cellular antimicrobial. As typical lipophilia, they pass through the cell wall and cytoplasmic membrane and disrupt the structure of their different layers of poly saccharides, fatty acid and phospholipid and permeabilizethem (Carson et al., 2002). Cytotoxicity appears to include such membrane damage. In bacteria, the permeabilization of the membranes is associated with loss of ion and reduction of membranes potential, collapse of the proton pump and depletion of the ATP pool (Turina et al., 2006). Moreover, it was evident that essential oil could coagulate the cytoplasm (Gustatson et al., 1998) and damage lipid and proteins (Burt, 2004).

\section{Semen quality:}

Data presented in Table 1 showed significant decrease $(\mathrm{P} \leq 0.05)$ in semen characteristics (volume, concentration, motility, live sperm and abnormal spermatozoa) and increase in reaction time of PC group compared with NC group. In the same context, the semen characteristics were significantly $(\mathrm{P} \leq 0.05)$ increased in all treated groups at $7^{\text {th }}$ and $14^{\text {th }}$ toward the NC levels.

Obtained data in previous figures indicated a significant decrease $(\mathrm{P} \leq 0.05)$ in testosterone, TAC and increase in cortisol, $\mathrm{T}_{3}, \mathrm{~T}_{4}$ and MAD in serum blood infested male rabbits with Sarcoptic Scabies.

Nabila et al., (2013) mentioned that sarcoptic mange is associated with reduced size-corrected testes mass in Iberian ibex which supports the hypothesis that parasitism is a determining factor in gonad plasticity in male mammals. Santiago-Moreno et al., (2010) examined the relationship between sperm quality and the level of parasitism in infested Iberian ibex and looked separately for linear relationships. Testis size is intimately associated to testosterone dynamics (Toledano-Díaz et al., 2007), and testosterone is predictive of a male's rank trajectory (Beehner et al., 2006). Consequently, reduced testes mass in mange individual may not only threaten reproductive success through sperm competition (Preston et al., 2003), but may also, severely hinder the recruitment, the courtship and eventually the mating success of infested hosts. 
Table (1): Effect of therapeutics by ivermectin, garlic, cinnamon, and combination of them on semen characteristics and reaction time of male rabbits.

\begin{tabular}{|c|c|c|c|c|c|c|}
\hline Groups & $\begin{array}{l}\text { Volume } \\
\text { (ml) }\end{array}$ & $\begin{array}{c}\text { Sperm } \\
\text { Concentration } \\
\left(10^{6} / \mathrm{mL}\right) \\
\end{array}$ & Motility (\%) & $\begin{array}{l}\text { Live Sperm } \\
(\%)\end{array}$ & $\begin{array}{l}\text { Abnormal } \\
\text { Sperm (\%) }\end{array}$ & $\begin{array}{c}\text { Reaction Time } \\
\text { (sec) }\end{array}$ \\
\hline \multicolumn{7}{|c|}{ Negative control (NC) } \\
\hline $1^{\text {st }}$ day & $0.71 \pm 0.017^{\mathrm{Aa}}$ & $389 \pm 31.9^{\mathrm{Aa}}$ & $82.4 \pm 1.12^{\mathrm{Aa}}$ & $86.8 \pm 3.56^{\mathrm{Aa}}$ & $15.2 \pm 0.45^{\mathrm{Ba}}$ & $31.7 \pm 1.21^{\mathrm{Ba}}$ \\
\hline $7^{\text {th }}$ day & $0.69 \pm 0.015^{\mathrm{Aa}}$ & $401 \pm 22.7^{\mathrm{Aa}}$ & $83.1 \pm 1.98^{\mathrm{Aa}}$ & $85.1 \pm 4.24^{\mathrm{Aa}}$ & $14.9 \pm 0.52^{\mathrm{Ba}}$ & $30.8 \pm 1.34^{\mathrm{Ba}}$ \\
\hline $14^{\text {th }}$ day & $0.72 \pm 0.013^{\mathrm{Aa}}$ & $425 \pm 30.1^{\mathrm{Aa}}$ & $80.9 \pm 1.75^{\mathrm{Aa}}$ & $86.2 \pm 3.10^{\mathrm{Aa}}$ & $16.1 \pm 0.63^{\mathrm{Ba}}$ & $32.1 \pm 1.02^{\mathrm{Aa}}$ \\
\hline \multicolumn{7}{|c|}{ Positive control (PC) } \\
\hline $1^{\text {st }}$ day & $0.42 \pm 0.016^{\mathrm{Ba}}$ & $219 \pm 17.5^{\mathrm{Ba}}$ & $60.7 \pm 1.09^{\mathrm{Ba}}$ & $72.7 \pm 1.45^{\mathrm{Ba}}$ & $22.1 \pm 0.48^{\mathrm{Ab}}$ & $35.7 \pm 0.96^{\mathrm{ABa}}$ \\
\hline $7^{\text {th }}$ day & $0.36 \pm 0.021^{\mathrm{Ca}}$ & $207 \pm 22.8^{\mathrm{Ca}}$ & $60.4 \pm 2.50^{\mathrm{Ca}}$ & $71.2 \pm 1.20^{\mathrm{Ba}}$ & $25.2 \pm 1.01^{\mathrm{Aab}}$ & $33.1 \pm 1.04^{\mathrm{ABab}}$ \\
\hline $14^{\text {th }}$ day & $0.31 \pm 0.012^{\mathrm{Ba}}$ & $202 \pm 19.1^{\mathrm{Ca}}$ & $60.1 \pm 2.06^{\mathrm{Ba}}$ & $69.7 \pm 1.44^{\mathrm{Ba}}$ & $26.3 \pm 0.99^{\mathrm{Aa}}$ & $30.1 \pm 1.11^{\mathrm{Ab}}$ \\
\hline \multicolumn{7}{|c|}{ Ivermectin 1\% (IV) } \\
\hline $1^{\text {st }}$ day & $0.49 \pm 0.017^{\mathrm{Bb}}$ & $243 \pm 18.5^{\mathrm{Bb}}$ & $68.7 \pm 3.21^{\mathrm{Bb}}$ & $75.4 \pm 0.95^{\mathrm{Bb}}$ & $17.2 \pm 0.73^{\mathrm{Ba}}$ & $35.7 \pm 1.19^{\mathrm{Aa}}$ \\
\hline $7^{\text {th }}$ day & $0.56 \pm 0.019^{\mathrm{ABab}}$ & $368 \pm 25.2^{\mathrm{ABa}}$ & $78.6 \pm 2.25^{\text {ABab }}$ & $80.7 \pm 1.05^{\mathrm{Aab}}$ & $15.3 \pm 0.82^{\mathrm{Ba}}$ & $33.1 \pm 0.97^{\mathrm{ABab}}$ \\
\hline $14^{\text {th }}$ day & $0.69 \pm 0.020^{\mathrm{Aa}}$ & $397 \pm 27.4^{\mathrm{Aa}}$ & $80.4 \pm 3.11^{\mathrm{Aa}}$ & $82.8 \pm 1.11^{\mathrm{Aa}}$ & $14.6 \pm 0.99^{\mathrm{Ba}}$ & $30.1 \pm 1.07^{\mathrm{Ab}}$ \\
\hline \multicolumn{7}{|c|}{ Garlic oil (GO) } \\
\hline $1^{\text {st }}$ day & $0.47 \pm 0.028^{\mathrm{Bb}}$ & $241 \pm 20.4^{\mathrm{Bb}}$ & $67.8 \pm 2.08^{\mathrm{Bb}}$ & $73.9 \pm 1.31^{\mathrm{Bb}}$ & $18.1 \pm 0.73^{\mathrm{Ba}}$ & $36.2 \pm 1.25^{\mathrm{Aa}}$ \\
\hline $7^{\text {th }}$ day & $0.53 \pm 0.039^{\mathrm{Bb}}$ & $355 \pm 27.5^{\mathrm{Ba}}$ & $75.8 \pm 1.97^{\mathrm{Bab}}$ & $82.1 \pm 1.23^{\mathrm{Aa}}$ & $15.6 \pm 0.49^{\mathrm{Ba}}$ & $34.1 \pm 1.34^{\mathrm{ABa}}$ \\
\hline $14^{\text {th }}$ day & $0.66 \pm 0.030^{\mathrm{Aa}}$ & $391 \pm 28.5^{\mathrm{Aa}}$ & $80.4 \pm 3.11^{\mathrm{Aa}}$ & $80.7 \pm 1.25^{\mathrm{Aab}}$ & $15.4 \pm 0.91^{\mathrm{Ba}}$ & $32.3 \pm 1.10^{\mathrm{Aa}}$ \\
\hline \multicolumn{7}{|c|}{ Cinnamon oil $(\mathrm{CO})$} \\
\hline $1^{\text {st }}$ day & $0.46 \pm 0.018^{\mathrm{Bb}}$ & $239 \pm 20.4^{\mathrm{Bb}}$ & $66.9 \pm 2.21^{\mathrm{Bb}}$ & $75.3 \pm 1.01^{\mathrm{Bb}}$ & $17.9 \pm 0.83^{\mathrm{Ba}}$ & $37.1 \pm 1.55^{\mathrm{Aa}}$ \\
\hline $7^{\text {th }}$ day & $0.51 \pm 0.019^{\mathrm{Bb}}$ & $357 \pm 28.5^{\mathrm{Ba}}$ & $75.1 \pm 1.95^{\mathrm{Bab}}$ & $79.6 \pm 0.93^{\mathrm{Aab}}$ & $16.1 \pm 0.69^{\mathrm{Ba}}$ & $35.2 \pm 1.74^{\mathrm{ABab}}$ \\
\hline $14^{\text {th }}$ day & $0.64 \pm 0.020^{\mathrm{Aa}}$ & $388 \pm 32.2^{\mathrm{Aa}}$ & $80.4 \pm 2.51^{\mathrm{Aa}}$ & $83.1 \pm 1.05^{\mathrm{Aa}}$ & $15.7 \pm 0.97^{\mathrm{Ba}}$ & $33.8 \pm 1.60^{\mathrm{Ab}}$ \\
\hline \multicolumn{7}{|c|}{ Mixture of (garlic + cinnamon) oils (MO) } \\
\hline $1^{\text {st }}$ day & $0.45 \pm 0.025^{\mathrm{Bb}}$ & $236 \pm 17.4^{\mathrm{Bb}}$ & $65.8 \pm 1.81^{\mathrm{Bb}}$ & $70.8 \pm 1.31^{\mathrm{Bb}}$ & $17.4 \pm 0.63^{\mathrm{Ba}}$ & $37.1 \pm 0.85^{\mathrm{Aa}}$ \\
\hline $7^{\text {th }}$ day & $0.54 \pm 0.029^{\mathrm{Bb}}$ & $364 \pm 22.5 \mathrm{~A}^{\mathrm{Ba}}$ & $74.9 \pm 2.05^{\mathrm{Bab}}$ & $80.5 \pm 1.33^{\mathrm{Aa}}$ & $16.7 \pm 0.79^{\mathrm{Ba}}$ & $35.2 \pm 1.04^{\mathrm{ABab}}$ \\
\hline $14^{\text {th }}$ day & $0.65 \pm 0.025^{\mathrm{Aa}}$ & $378 \pm 24.5^{\mathrm{Ba}}$ & $79.5 \pm 2.71^{\mathrm{Aa}}$ & $82.4 \pm 1.45^{\mathrm{Aa}}$ & $15.6 \pm 0.91^{\mathrm{Ba}}$ & $32.8 \pm 11.04^{\mathrm{Ab}}$ \\
\hline
\end{tabular}

Means within the same column carrying different small letters are significantly different at $(\mathrm{P} \leq 0.05)$,

Means within the same column under each parameter carrying different capital letters are significantly different at $(\mathrm{P} \leq 0.05)$. Values are expressed as Lsmeans $\pm \mathrm{SE}$;

Barth and Bowman (1994) detected that low testosterone may interfere with the same cellular metabolic processes, leading to similar outcomes in defects of the cells affected during spermatid metamorphosis

Correlation coefficients between seminal hormonal levels and physical semen parameters in male rabbits showed that the level of $\mathrm{T}_{3}, \mathrm{~T}_{4}$ and testosterone had significant positive correlations with good semen characteristics (ejaculate volume, sperm motility, sperm cell concentrations, total number of sperms output and number of motile sperms per ejaculate) and had significant negative correlations with bad semen characteristics (high in each of reaction time, dead sperm\%, sperm abnormality\% and acrosomal 
abnormality\%). In rats rendered thyrotoxic by $\mathrm{T}_{4}$ resulted in decreased serum gonadotropin levels (Schneider et al., 1979), decrease in total lipids, cholesterol, and phospholipids in testes, and synthesize increased amounts of testosterone (Aruldhas, et al., 1986). However, $\mathrm{T}_{3}$ also plays a significant role in differentiation of the seminiferous epithelium, and studies in rodents have shown that $T_{3}$ is an important factor in maturation of Leydig cells. The presence of $T_{3}$ is necessary to initiate differentiation of mesenchymal cells into Leydig progenitor cells, and $\mathrm{T}_{3}$ works in concert with other hormones [luteinizing hormone (LH) and IGF-I] to promote Leydig cell development (Mendis-Handagama and Ariyaratne, 2001). Also it was suggested that $T_{3}$ is a component of the neuroendocrine system that regulates seasonal cycles of reproductive activity (Dutta et al., 2013). On the other hand, cortisol shows the opposite finding with $\mathrm{T}_{3}, \mathrm{~T}_{4}$ and testosterone. Cortisol levels had significant negative correlations with good semen characteristics and significant positive correlations with bad semen characteristics. Therefore, the level of any one of these hormones could be used in detection of semen quality to predict the reproductive performance of male rabbits under different conditions and lighting.

Agarwal et al., (2005) mentioned that the oxidative damage caused by free radicals was a major cause of idiopathic oligospermia and even had adverse effects on sperm structure and produces sperm abnormalities (Coskun et al., 2005). There are two antioxidant systems in the human body (antioxidant defense system), containing proteins such as albumin and ceruloplasmin which bind to metal ions and prevent the formation of active species, and thus, prevent a chain reaction of reactive oxygen species. While scanning the system, antioxidants like vitamin $\mathrm{E}$, vitamin $\mathrm{C}$, glutathione peroxidase, eliminate produced ROS in order to inhibit plasma membrane lipid peroxidation.

Harmony with current work, Onakpa, et al., (2010) indicated dramatic changes in semen parameters represented by significant decrease in the sperm count as well as increase in the sperm abnormalities followed ivermectin injection. The deleterious effect of ivermectin on sperm could be due to the oxidant nature of certain neurotransmitter metabolites which triggered by ivermectin (Shoeb, 2013). Additionally, treatment with ivermectin lead to lack of spermatogenesis stimulating hormone ( $\mathrm{SSH}$ ) resulting in decrease in sperm concentration and lack of active testosterone, consequently, increase in sperm abnormalities occurred which varies from abnormalities in head as enlarged 
head, abnormal middle piece and abnormal tail, which may be coiled, bent tail (Onakpa, et al., 2010). Moreover, Low levels of sperms concentration after ivermectin injection may be due to effect of ivermectin in a dose dependent manner on muscle fiber of male reproductive system leading to decrease in the total force of ejaculation (Burg et al., 1979). Accordingly, this ensures a persistence harmful effect of ivermectin on the reproductive organs function. However, Orgebin Crist et al., (1976) mentioned that the composition of the epididymis fluid may be affected the mechanism necessary for sperm maturation, transport and storage. On the other hand, Rabab et al., (2015) recorded the treatment of bulls with ivermectin improved the semen quality, total sperm output ejaculate and the activity of acid and alkaline phosphatases of seminal plasma.

Garlic contains a wide variety of phytochemicals and microcomponents such as trace elements, vitamins, fructans, flavonoids, and sulphur compounds, which can effectively scavenge free radicals (Khaki et al., 2011). Oi et al., (2001) demonstrated that the increased concentration of testicular testosterone after feeding rats with $8 \mathrm{~g}$ of garlic powder was due to an increase in luteinizing hormone (LH) level in plasma. Indeed, crude garlic and garlic powder may have the same active compounds (Oi et al., 2001). Ola-Mudathir et al., (2008) indicated that aqueous extracts of garlic caused an increase in the catalase activity and protect the testis and spermatozoa against cadmium toxicity.

Hammami et al., (2008) found that rats fed with $10 \%, 15 \%$ or $30 \%$ Allium sativum (AS) containing diet, showed a significant increase in the number of empty seminiferous tubules in testes and a decrease in the level of testosterone. Male rats fed with crude garlic showed damaged testicular function and spermatogenesis. Also, a decreased prostate weight was associated with a reduction in citric acid content in rats fed with $30 \%$ garlic.

Cinnamomum (family of Lauraceae) species contain volatile oils, tannins, terpenoids, mucilage, oxalates and starch. Different chemical constituents of C.zeylanicumare known to have significant germicidal, antiulcerogenic and cytotoxic effects. Shah et al., (1998) demonstrated that the extract of cinnamomum increased the weight of testes, caudae epididymidies and seminal vesicles in the treated male mice, indicating a possible stimulation of hormonal levels in the animals. Also, the sperm count and motility of the treated animals were significantly higher than the control group.

Ranasinghe et al., (2013) mentioned that C. zeylanicum has $65.3 \%$ antioxidant activity and also a very strong free radical scavenging activity. 
According to in-vivo and in-vitro studies, $C$.zeylanicum has antimicrobial, antiparasitic, antioxidant and free radical scavenging properties. Furthermore, it could lower serum cholesterol, blood pressure and blood glucose in diabetic people. Khaki et al., (2010) showed that using $75 \mathrm{mg} / \mathrm{kg}$ of $\mathrm{C}$. zeylanicum as an antioxidant in food increased SOD, GPX, and CAT, leading to the elimination of ROS and elevation of testosterone secretion; it could enhance its fertility properties.

Finley, Arash Khaki (2015) demonstrated that the GPX, CAT and SOD contained by $C$. zeylanicum could increase serum antioxidant levels male rats. Therefore, it has the potential to restore fertility and normal spermatogenesis, sperm quality parameters, and to improve testosterone level and sperm quality parameters, such as population, viability and motility, while in the meantime decreasing the MAD level.

Conclusively, from these results, it could be concluded that five percent of garlic or cinnamon oil is so effective in treating rabbits injured by Sarcoptec scabei compared to ivermectin with no side effects on liver and kidney functions or semen characteristics.

\section{REFERENCES}

Abdel-Fattah. A.A.; Kh.M. Sallam and K.A. Moustafa (2011). A novel method for determination of $\mathrm{T}_{3}$ and $\mathrm{T}_{4}$ hormones, associated with its physicochemical studies. Radiochemistry, Volume 53, Issue 2, pp 213-220.

Adams, R. (2007). Identification of essential oil components by gas chromatography /mass spectrometry, $4^{\text {th }}$ ed.; Allured Publishing Corporation: Carol Stream, IL, USA. 25-39.

Agarwal, A.; S.A. Prabakaran and T.M. Said (2005). Prevention of oxidative stress injury to sperm. J Androl., 26: 654-60.

Arash, Khaki (2015). Effect of Cinnamomum zeylanicumon on spermatogenesis. Iranian Red Crescent Medical Jour., Vol. 17(2): 1-5.

Arise, R.O. and S.O. Malomo (2009). Effects of ivermectin and albendazole on some liver and kidney function indices in rats. Afr. J. Biochem. Res., 3: 190-197.

Aruldhas, M.M.; Valivullah; H.M. Srinivasan; N. Govindarajulu and P. Roleof (1986). Thyroid on testicular lipids in prepubertal, pubertal and adult rats. I. Hyperthyroidism. Biochim. Biophys. Acta. 881: 4629.doi:10.1016/0304-4165(86) 90040-1. 
Ashang, B.U. (2009). Effect of therapeutic and toxic doses of ivermectin (Mectizan) on total serum proteins and hepatic enzymes of wistar albino rats. Int. J. Biol. Chem., 3: 142-147. DOI: 10.3923 /ijbc., 142.147.

Atakisi, E.; O. Atakisi; B. Topcu and M. Uzun (2009). Effects of therapeutic dose of ivermectin on plasma nitric oxide and total antioxidant capacity in rabbits. Euro. Rev. for Med. and Phar. Sci., 13: 425-429.

Barth, A.D. and P.A. Bowman (1994). The sequential appearance of sperm abnormalities after scrotal insulation or dexamethasone treatment in bulls. Can. Vet. J., 35: 93-102.

Beehner, J.C.; T.J. Bergman; D.L. Cheney; R.M. Seyfarth and P.L. Whitten (2006). Testosterone predicts future dominance rank and mating activity among male chacma baboons. Behav. Ecol. Sociobiol., 59: 469479.

Behera, S.K., U. Dimri, S.K. Singh and R.K. Mohanta (2011). The curative and antioxidative efficiency of ivermectin and ivermectin + vitamin Eselenium treatment on canine Sarcoptes scabiei infestation. Vet. Res. Commun., 35: 237-244. DOI: 10.1007/s11259-011-9468-8.

Bergman, T.J.; J.C. Beehner; D.L. Cheney; R.M. Seyfarth and P.L. Whitten (2006). Interactions in male baboons: the importance of both males' testosterone. Behav. Ecol. Sociobiol., 59: 480-489.

Burg, R.W.; B.M. Miller; E.E. Baker; J. Bimbeum; J.A. Currie; R. Harman; V.L. Kong; R.I. Monaghan; G. Olson; I. Putter; J.P. Tunac; H. Wallick; E.O. Stapley; R. Oiwa and S. Omura (1979). The action of avermectin on identified central neurons from helix and its interaction with acetylcholine and gamma aminobutyric acid response. Antimicrob. Agents Chemo., 15: 361-367. PMID: 2873943.

Burt, S., (2004). Essential oils: their antibacterial properties and potential applications in foods-a review. Int. J. Food Microbial., 94:223-253.

Canadian liver foundation, Bringing liver research to life (2015). All rights reserved. Charitable Registration \# 106862949 RR0001.

Carmia Borek., (2001). Antioxidant Health Effects of Aged Garlic Extract1, $J$. Nutr., 131: 1010S-1015S.

Carson, C.F.; B.J. Mee and T.V. Riley (2002). Mechanism of action of Melaleuca alternifolia (tea tree) oi on staphylococcus aureus determined by tim-kill, lysis, leakage and salt tolerance assays and electron microscopy. Antimicrob. Agents Chemother, 46:1914-1920. 
Chibundu, U.C., (2005). Response of pre-pubertal bucks to administration of estradiol $\beta$. Project Report, Federal University of Technology, Owerri pp. 30.

Correa, J.R. and P.M. Zavos (1996). Preparation and recovery of frozen thawed bovine spermatozoa via various sperm selection techniques employed in assisted reproductive technologies. Theriogenology, 46: $1225-1232$.

Coskun, O.; M. Kanter; A. Korkmaz and S. Oter (2005). Quercetin, a flavonoid antioxidant, prevents and protects streptozotocin-induced oxidative stress and beta-cell damage in rat pancreas. Phar. Res., 51: 117-23.

David, B.P.; R.V. Kumar; K.S. Paliniswami; V.B. Kadwad and N. Sivaprasad (1998). Estimation of thyroid hormones in animal's samples. Ind. Vet. J. , 75:565-566.

Doumas, B., (1971). Colourimetric method for albumin determination. Clin. Chim. Acta, 31: 87-92.

Duncan, D.B., (1955). Multiple range and multiple F. test. Biometrics 11:42.

Dutta, S.; K.R. Joshi; P. Sengupta and K. Bhattacharya (2013). Unilateral and bilateral cryptorchidism and its effect on the testicular morphology, histology, accessory sex organs and sperm counting laboratory mice. $J$. Hum. Reprod. Sci., (6): 106-10. doi:10.4103/0974-1208.117172.

El-Shater, M.A.; Hanan, M.S.; Sobbhy and Gehan, J. Shehab (1998). Some pharmacological and pathological studies on Allium sativum (garlic). Assiut Vet. Med. J., 38 (76): 264-281.

El-Shenawy, N.S., (2010). Effects of insecticides fenitrothion, endosulfan and abamectin on antioxidant parameters of isolated rat hepatocytes. Toxicol. Vitro, 24: 1148-1157. PMID: 20214973.

El-Speiy, M.E.; M.A. El-Sawy; M.A. Tony and T.A. Sadaka (2016). Comparative studies on reproductive male rabbits as affected by ivermectin or both of garlic and cinnamon oils treatments. a: Acaricidal efficacy of ivermectin, garlic and cinnamon oils against Sarcoptes scabiei in suffering infested rabbits. Egyptian Journal of Rabbit Science, 26 (1): 21 - 38.

Eman, E.E. and O.E.L. Abdella (2000). Effect of ivermectin and moxidectin on fertility and some biochemical parameters in male rabbits. Egypt $J$. Agric Res .,78(1):293-301. 
Emtenan, M. Hanafi; Nagwa A. Maghraby; Manal M. Ramadan; Mona A. Mahmoud and Hewida M. El-Allawy (2010). Aromatherapy of cinnamomum zelanicium Bark oil for treatment of Scabies in rabbits with emphases on the productive performance; American-Eurasian Agaric and Environ.Sci.,7(6):719-727.

Fichi, G.; G. Flamini; F. Giovanelli; D. Otranto and S. Perrucci (2007a). Efficacy of an essential oil of Eugenia caryophyllata against Psoroptescuniculi. Experi. Parasi., 115: 168-172.

Garris, G.I.; J.B. Prullage; J.L. Prullage; F.C. Wright and J.A. Miller (1991). Control of Psoroptes cuniculi in captive white-tailed deer with ivermectin-treated corn. Journal of Wildly Dis., 27(2):254-257.

Gines, P. and V. Arroyo (2000). Is there still a need for albumin infusions to treat patients with liver disease. Gut.; 46:588-590. [PMC free article] [PubMed]

Gustatson, J.E., Y. Liew; S. Chew; J.l. Markham; H.C. Bell; S.G. Wyllie and J.R. Warmington (1998). Effect of tea tree oil on Escherichia coli. Lett. Appl. Microbiol., 26: 194-198.

Hammami, I.; A. Nahdi; C. Mauduit; M. Benahmed and M. Amri (2008). The inhibitory effects on adult male reproductive functions of crude garlic (Allium sativum) feeding. Asian Journal of Andro., 10 (4): 593-601.

Harrenstien, L.; E.J. Gentz and J.W. Carpenter (1995). How to handle respiratory, ophthalmic, neurological and dermatologic problems in rabbits. Proceedings of the Symposium on Rabbit Medicine, 4 April, Lenexa, Kansas. Vet. Med. , 90 (4) :373-380.

Henry, R.J. (1974). Clinical Chemistry, Principles And Techniques. 2nd Ed., Harper and Raw, 525.

Hughes, D.P.; J. Kathirithamby; S. Turillazzi and L. Beani (2004). Social wasps desert the colony and aggregate outside if parasitized: parasite manipulation. Behav. Ecol., 15: 1037-1043.

Hutchinson, G.W.; K. Dawson; C.C. Fitzgibbon and P.J. Martin (2009). Efficacy of an injectable combination anthelmintic (nitroxynil +clorsulon+ivermectin) against early immature Fasciola hepatica compared to triclabendazole combination flukicides given orally or topically to cattle. Vet. Parasitol., 162: 278- 284. PMID: 19375232. 
Ibrahim, S.A.M.; M.M.H. Osfor and G.M. El-Mallah (2000). Garlic and Panaxginseng as dietary supplements against the contamination with mercuric chloride in New Zealand rabbits. Egypt. J. Rabbit Sci., 10 (2): 207222.

Ide, N.; A.B. Nelson and B.H.S. Lau (1996). Aged garlic extract and its constituents inhibit $\mathrm{Cu} 12$-induced oxidative modification of low density lipoproteins. Planta Med., 63: 263-264.

Ippoushi, K.; H. Ito; H. Horie and K. Azuma (2005). Mechanism of inhibition of peroxynitrite- induced oxidation and nitration by [6]-gingerol. Planta-Medica, 71: 563-566.

Jenkins J., (2000). Rabbit and ferret liver and gastrointestinal testing. In: A. Fudge, Editor. Laboratory Medicine: Avian and Exotic Pets. Philadelphia: WB Saunders; $\mathrm{p}$ 291-304.

Kadry, M.; I. Sadek and H. M. Shaheen (2015). The biochemical effects of ivermectin on reproductive hormones and mineral homeostasis in Baladi cows post parturition. Veterinarski Arhiv., 85 (1), 95-103.

Kanbur, M.; O. Atalay; A. Ica; G. Eraslan and Y. Cam (2008). The curative and antioxidative efficiency of doramectin and doramectin + vitamin A, D3, E treatment on Psoroptes cuniculi infestation in rabbits. Res. Vet. Sci., 85: 291-293.

Kevin, M.; D.O. Pantalone and C.C.D. Ecnu (2012). Male hypogonadism: More than just a low testosterone.Cleveland Clin. J. Med., 79: 717-725. DOI: $10.3949 /$ ccjm. 79a. 11174.

Khaki, A.; F. Fathiazad; M. Nouri; A. Khaki; N.A. Maleki and H.J. Khamnei (2010). Beneficial effects of quercetin on sperm parameters in streptozotocin induced diabetic male rats. Phytother. Res., 24(9): 1285-91.

Khaki, A.; L. Farzadi; S. Ahmadi and E. Ghadamkheir (2011). Recovery of spermatogenesis by Allium cepa in Toxoplasma gondii infected rats. African Journal of Pharmacy and Pharmacology, 5(7): 903-907.

Khan, M. A.; A.H. Shah; A. Maqbol; N. Khan and Z.U. Rahman (2012). Miticidal activity of methanolic extract of vitex negundo - lam against anti Sarcoptes scabie in animals. The Jour. of Anim. and Plant Sci., 22(2): 102-107.

Kyo, E.; N. Uda; A. Suzuki; M. Kakimoto; M. Ushigina; S. Kasuga and Y. Itakura (1998). Immunomodulation and antitumour activities of aged garlic extract. Phytomedicine, 5 (4):259-267. 
Kyriazakis, I. and E. Day (1998). Does the study of feeding behavior benefit from a teleonomic framework. Nutr. Res. Rev., 11:223-229.

Ledezma, E. and C. R. Apitz (1998). From folklore to molecular mechanism: the example of ajoene. Interciencia, 23 (4): 227-231.

Mahmoud, A.A.; T.S. Allam and A.O. Elkhatam (2014). Biochemical and circulating oxidative stress biomarkers in Egyptian buffaloes (Bubalus bubalis) infested by sarcoptic mange; Glob. Vet., 13 (4): 656-661.

Marieb, E.N. and K. Hoehn (2010). Human Anatomy and Physiology. $8^{\text {th }} E d$., Benjamin Cummings, San Francisco, ISBN-10: 0321543122, pp: 1229.

Mendis-Handagama, S.M. and H.B. Ariyaratne (2001). Differentiation of the adult Leydig cell population in the postnatal testis. Biol. Reprod. 65: 66071. doi: 10.1095/biolreprod, 65.3.660.

Meredith, A. and L. Rayment (2000). Liver disease in rabbits. Seminars in Avian and Exotic Pet Medicine; 9 (3): 146-152.

Mohamed I. El-Katcha; Mosaad A. Soltan; Mohmoud S. Essi (2016). Effect of Garlic Extract Supplementation on Growth Performance, Nutrient Digestibility and Some Blood Serum Biochemical Changes of Fattening Lambs, AJVS. , 48(2): 124-133.

Muehlenbein, M.P. and D.P. Watts (2010). The costs of dominance: testosterone, cortisol and intestinal parasites in wild male chimpanzees. Biopsychosoc Med., 9:4-21.

Muthukumaran, S.; A. Sudheer; V.P. Menon and N. Nalini (2008). Protective effect of quercetin on nicotine-induced pro-oxidant and antioxidant imbalance and DNA damage in Wistar rats. Toxicol., 243: 207-215.

Nabila, El-Desouki; Ghada A. Tabl; A.E.B. Zeidan; M.A. Tag El-Deen and Rabab A. Kamel (2013). Ultrastructure study of frozen-thawed spermatozoa of friesian bulls treated by certain anthelmintic drugs. Jour. of Ameri. Sci., 9 (7) 215-221.

Oi, Y.; M. Imafuku; C. Shishido; Y. Kominato and S. Nishimura (2001). Garlic supplementation increases testicular testosterone and decreases plasma corticosterone in rats fed a high protein diet. Journal of nutria., 131(8):2150-2156.

Ola-Mudathir, K.F.; S.M. Suru; M.A. Fafunso; U.E. Obioha and T.Y. Faremi (2008). Protective roles of onion and garlic extracts on cadmium induced changes in sperm characteristics and testicular oxidative damage in rats. Food and Chem. Toxicol., 46(12): 3604-3611. 
Onakpa, M.M.; O.P. Ajagbonna.; K.I. Onifade and M. Akande (2010). Ivermectin on semen and serum Sokoto buk. Int. J. Chem. Tech. Res., 2:738-743.

Orgebin-Crist, M.C.; B.J. Danzo and T.G. Cooper (1976). Re-examination of the dependence of epididymal sperm viability on the epididymal environment. Journal of Reprod. and Fert., 24: 115-128.PMID:1069848.

Orihuela, A.; V. Aguirre; C. Hernandez; I. Flores-Perez and P. Vazquez (2009). Breaking down the effect of electro-ejaculation on the serum cortisol response, heart and respiratory rates in hair sheep (Ovis Aries). JAVA, 8(10):1968-1972.

Preston, B.T.; I.R. Stevenson; J.M. Pemberton; D.W. Coltman and K. Wilson (2003). Overt and covert competition in a promiscuous mammal: the importance of weaponry and testes size to male reproductive success. Proc. R. Soc., B 270, 633-640.

Quinlan, G.J.; M.P. Margarson; S. Mumby; T.W. Evans and J.M. Gutteridge (1998). Administration of albumin to patients with sepsis syndrome: a possible beneficial role in plasma thiol repletion. Clin. Sci.; 95: 459-465.[PubMed].

Rabab, R. Elzoghby; Aziza Amin; Ahlam F. Hamouda and A. Ali (2015). Toxicological and pathological studies of Ivermectin on male albino rats. J. Am. Sci., 11(3): 73-83.

Ranasinghe, P; S. Pigera; G.A. Premakumara; P. Galappaththy; G.R. Constantine and P. Katulanda (2013). Medicinal properties of 'true' cinnamon (Cinnamomum zeylanicum): a systematic review. BMC Complement Altern Med., $13: 275$.

Reitman, S. and S. Frankel (1957). A colorimetric determination of serum AST and ALT enzymes. Amer. J. Clin. Path., 28: 56-58.

Roth, J.A. and M.L. Kaeberle (1982). Effect of glucocorticoids on the bovine immune system. J. Am. Vet. Med. Assoc. , 180:894- 901.

Saber, A. Sakr; Y. Ashraf and A. Albarakai (2014). Effect of cinnamon on cypermethrin-induced nephrotoxicity in albino rats. Internati. Jour. of Advanc. Res., Vol. 2, Issue 7, 578-586.

Santiago-Moreno, J.; M. Luzón; M.A. Coloma; A. Pulido-Pastor; F. Gómez- Guillamón; F.R.S. de la Vega; A. Toledano-Díaz and A. López-Sebastián (2010). Relationship between Iberian ibex (Capra pyrenaica) sperm quality and level of parasitism. Eur. J. Wildly. Res., 56: 605-611. 
Sarasa, M.; E. Serrano; R.C. Soriguer; J.E. Granados; P. Fandos; G. Gonzale and J.M. Pérez (2011). Negative effect of the arthropod parasite, Sarcoptes scabiei, on testes mass in Iberian ibex, Capra pyrenaica Vet.Parasitol, 175(3-4): 306-312.

SAS, (2002). SAS/ STAT User's Guide Statistics. SAS Institute INC., Cary, NC, USA.

Schneider, G.; K. Kopach; H. Ohanian; V. Bonne-fond; J.C. Mittler and N.H. Ertel (1979). The hypothalamic pituitary-gonadal axis during hyperthyroidismin the rat. Endocrinology, 105:674-9.doi:10. 1210/ endo 105-3-674.

Seddiek, S.A.; Hanem F. Khater; M.M. El-Shorbagy and A.M. Ali (2013). The acaricidal efficacy of aqueous neem extract and ivermectin against Sarcoptes scabiei var. cuniculi in experimentally infested rabbits. Parasitol. Res. 112: 2319-2330.

Selvakumar, K.; S. Bavithra; S. Suganya; F.A. Bhat and G. Kris hnamo orthy (2013). Effect of quercetin on haematobiochemical and histological changes in the liver of polychlorined biphenyls-induced adult male wistar rats. J. Biomarkers, 2013: 960125- 960136. DOI: 10.1155/2013/960125.

Shah, A.; A.H. Al-Shareef; A.M. Ageel and S. Qureshi (1998). Toxicity studies in mice of common spices, Cinnamomum zeylanicum bark and Piper longum fruits. Plant Foods for Human Nutrition (Formerly Qualitas Plantarum), 52(3): 231-239.

Shoeb, Q., (2013). Biochemical toxicity of ivermectin in Wister Albino rats. Am. Eurasian. J. Toxico. Sci., 5: 15-19.

Singh, S.K.; U. Dimri; M.C. Sharma; D. Swarup and B. Sharma (2011). Determination of oxidative status and apoptosis in peripheral blood of dogs with sarcoptic mange. Vet. Parasitol., 178: 330-338.

Singh, S.K.; U. Dimri; M.C. Sharma; D. Swarup; M. Kumar and R. Tiwary (2012). Psoroptes cuniculi induced oxidative imbalance in rabbits and its alleviation by using vitamins A, D3 E, and $\mathrm{H}$ as adjunctive remedial. Trop. Anim. Health. Prod., 44: 43-48.

Slantna, P.J.; C. Kuivinen; C. Ohlsen and L.G. Ekstrom (1989). Ivermectin residues in the tissues of swine and cattle. Effect of cooking and toxicological evaluation. Food Add. Contam., 6:475-481.

Smith, J.T. and D.T. Mayer (1955). Evaluation of sperm concentration by the hemacytometer method. Comparison of four counting fluids. Fertility and Sterility, 6: 271-275. 
Sonnenwirth, A. and L. Jarett (1980). Graduals Clinical Laboratory Methods and Diagnosis. Vol. (1), $8^{\text {th }}$ Ed., Mosby.

Suckow, M.A.; D.W. Brammer; H.G. Rush and C.E. Chrisp (2002). Biology and diseases of rabbits. In: Fox, J.G., Anderson, L.C., Loew, F.M. and Quimby, F.W. (Eds.): Laboratory animal medicine. $2^{\text {nd }}$ Ed. Academic Press, Inc., San Diego, California, pp.349-350.

Tibaldi, J.M. and M.I. Surks (1985). Effects of non-thyroidal illness on thyroid function. Med. Clin. North. Am.; 69: 899-911.

Toledano-Díaz, A.; J. Santiago-Moreno; A. Gómez-Brunet; A. PulidoPastor and A. López- Sebastián (2007). Horn growth related to testosterone secretion in two wild Mediterranean ruminant species: the Spanish ibex (Capra pyrenaica hispanica) and European mouflon (Ovis orientalis musimon). Anim. Reprod. Sci., 102: 300-307.

Tollba, A.A.H. and M.S.H. Hassan (2003). Using some natural additives to improve physiological and productive performance of broiler chicks under high temperature conditions. Egypt. Poult. Sci., 23 (II): 327-340.

Turina, A.; M. Nolan; J. Zygadlo and M. Perillo (2006). Natural terpens : self-assembly and membrane partition. Biophys. Chem., 122:101-113.

Virgin, J.R. and R.M. Sapolsky (1997). Styles of male social behavior and their endocrine correlates among low-ranking baboons. Am. J. Primatol., 42- ?????.

Vodo, S.; N. Bechi; A. Petroni; C. Muscoli and A.M. Aloisi (2013). Testosterone-induced effects on lipids and inflammation. Mediators Inflammat., 2013:183041-183048. DOI: 10.1155/2013/183041.

Walton, S.F. and B.J. Currie (2007). Scabies diagnostic problems for a global disease in human and animal populations. Clinic. Microbi. Rev., 20: 268279.

Wang, C.S.; T.T. Chang; W.J. Yao; S.T. Wang and P. Chou (2012). .Impact of increasing alanine aminotransferase levels within normal range on incident diabetes. J. Formos. Med. Assoc., 111: 201- 208. DOI: 10.1016/j.jfma.2011.04.004.

Wilke, T.J. and D.J. Utley (1987). Total testosterone, free androgenic index and calculated free testosterone by analog RIA method. Clin. Chem.; 33: 1372-75.

Williamson, E.M., (2002). Major herbs of Ayurveda. Elsevier Science Limited, pp. 32. 
Yuriko, Oi; Mika Imafuku; Chiaki Shishido; Yutaka Kominato; Syoji Nishimura and Kazuo Iwai (2001). Garlic supplementation increases testicular testosterone and decreases plasma corticosterone in rats fed a high protein diet. Jour. Nutr. , 131 (8): 2150-2156.

\section{مقارنة تأثير المعاملة بالإيفرمكتين وزيت الثوم أو زيت القرفة على الأب}

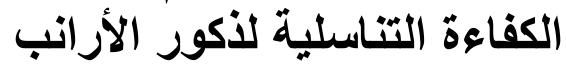

ب ـ تقدير بعض مكونات الدم، مستوى الهرمونات، صفات السائل المنوى.

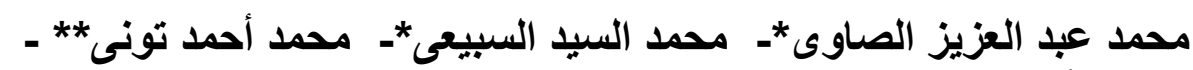
طارق أمين صدقه العزيز *معهد بحوث الأنتاج الحيو انى ــ مركز البحوث الزر اعية ـ وزارة الزر اعه ــ مصر.

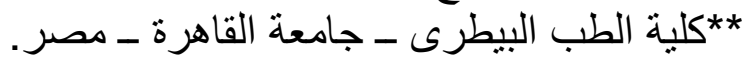

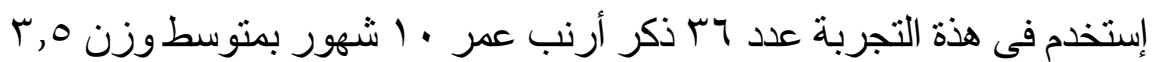

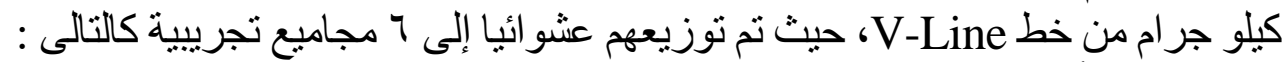
المجموعه الأولى : كنترول سالب (بدون عدوى بدون بدون معاملة).

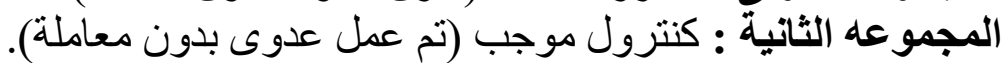

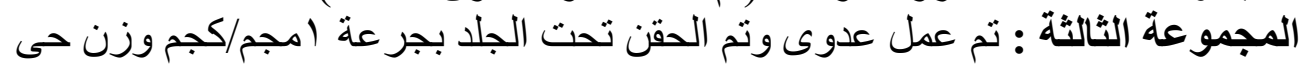

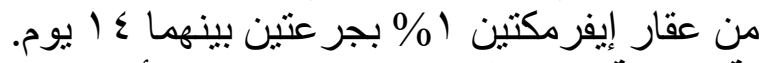

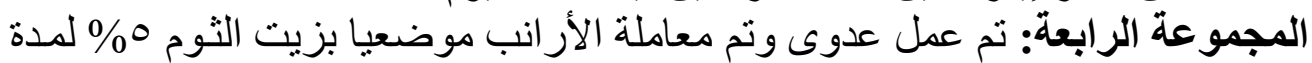

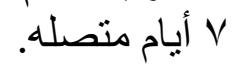

المجموعة الخامسة: نم عمل عدوى وتم معاملة الأر انب موضعيا بزيت القرفة ٪\% لمدة V أيام متصله.

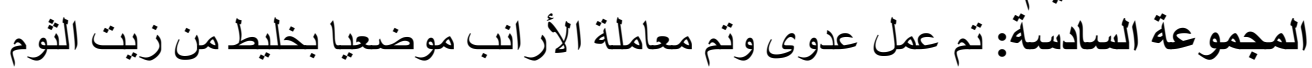

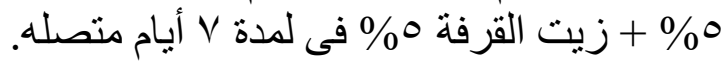

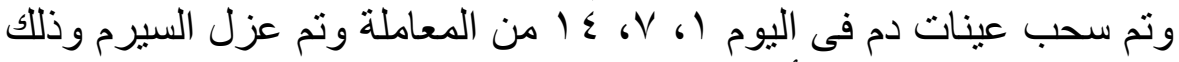

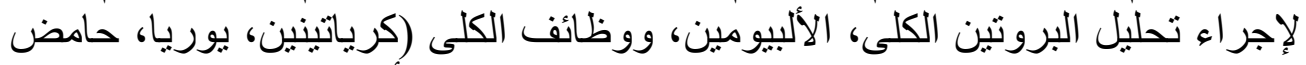

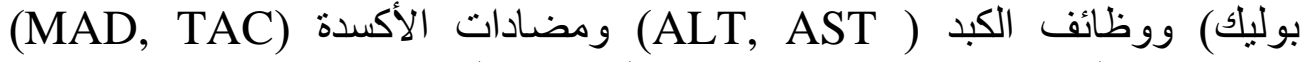
و هرمونات الدرقية ( T $)$ وهرمون الذكورة (التستستيرون) وهرمون الإجهاد

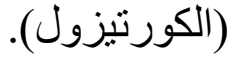




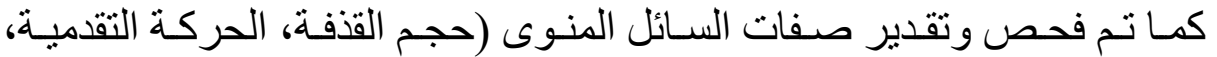

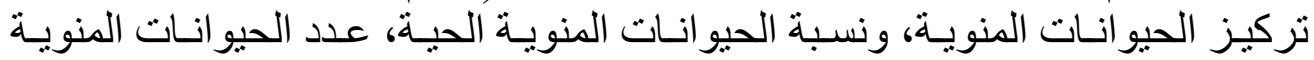

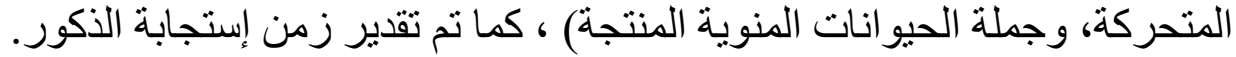
وقد أوضحت النتائج مايلى:

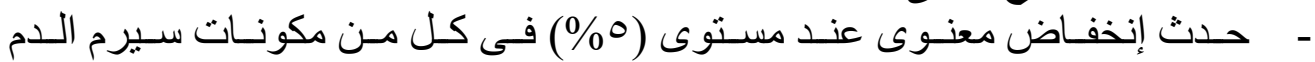

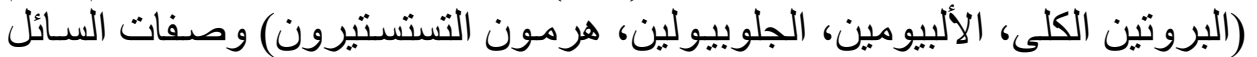

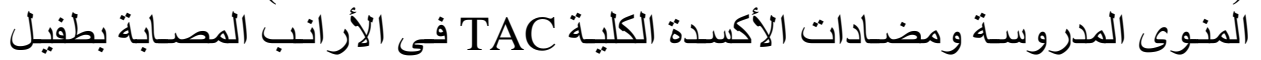

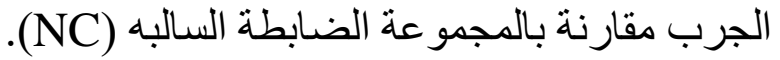

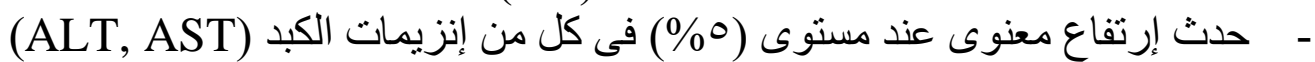

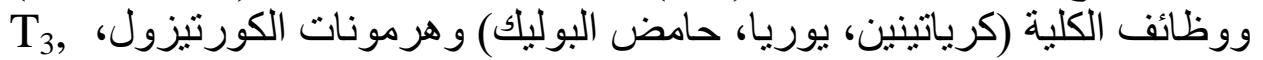
و وضنادات الأكسدة بالدم MAD في الأرانب المصابة بطفيل الجرب مهاب مقارنة بالمجمو عة الضنابطة السالبه (NC).

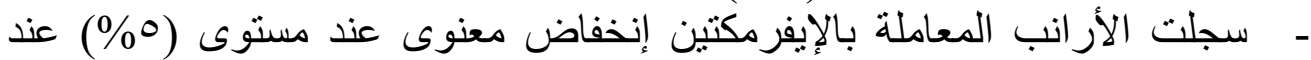

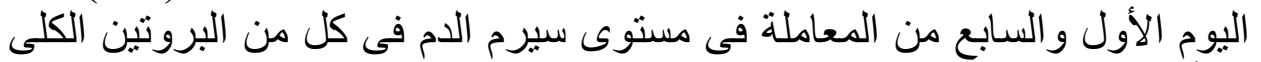

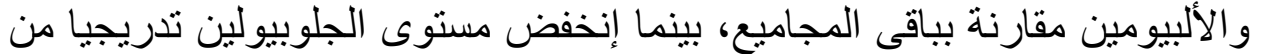

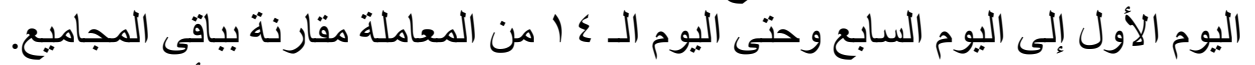
- لوحظت زيادة مستوى كل من مكونات سيرم الدم (البروتين الكلى، الألبيومين) و إنزيمات الكبد (ALT, AST) ووظائف الكلية (كرياتينين، يوريا، حامض فئن

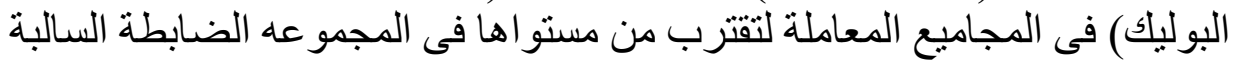
وذللك بداية من اليوم الـ V و الـ ع ا البع من بداية المعاملة. - - إنخفض مستوى إنزيمات الكبد (ALT, AST) ووظائف الكلية (كرياتينين، يوريا،

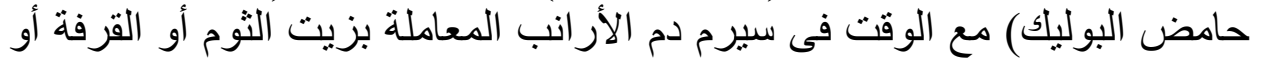

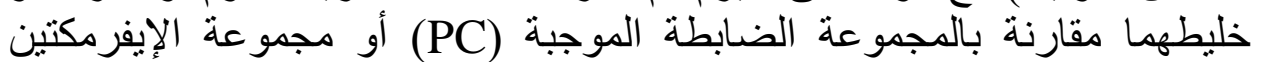

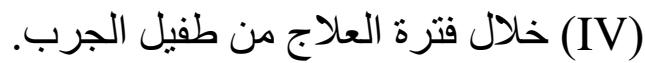

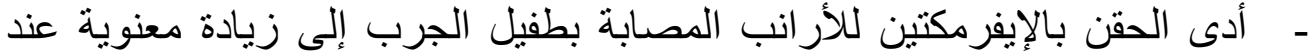
مستوى (\%) فى مستوى هرمون الكورتيزول، هرمونات الغدة الدرقية (T)

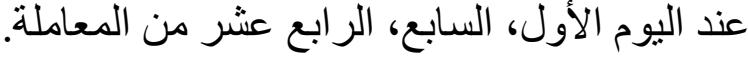

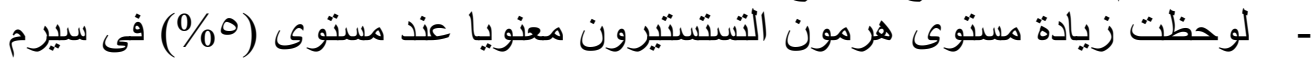

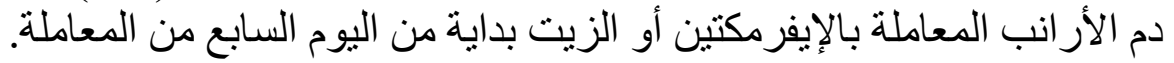

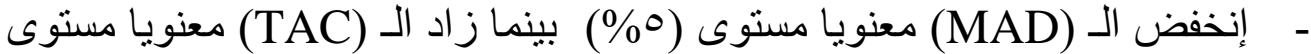

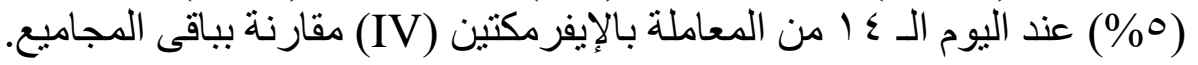


- دث إنخفاض معنوى عند مستوى (0\%) من اليوم الأول وحتى الر ابع عشر من

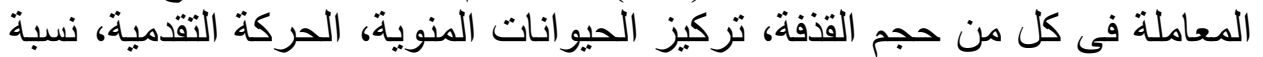

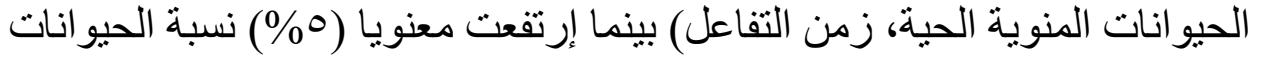

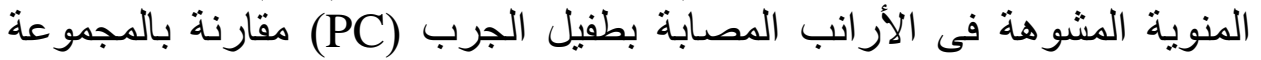

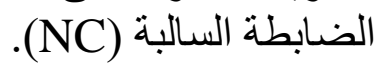
- وقد لوحظت زيادة فى صفات السائل المنوى المدروسة فى المجاميع المعاملة المانة

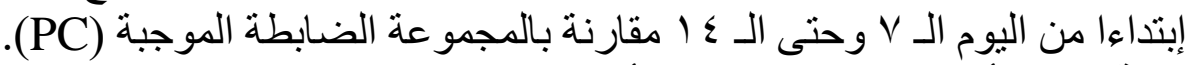

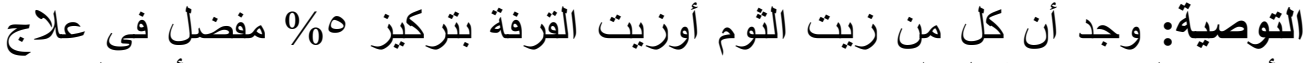

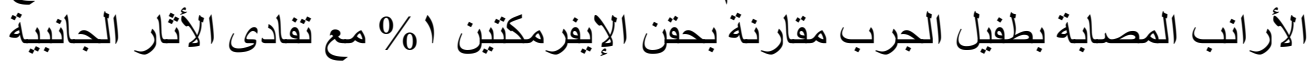
للإِيفرمكتين ا \% على إنزيمات الكبد ووظائف الكلى وصفات السائل المنوى الائل 